\title{
Blackberry extend shelf life by nanocellulose and vegetable oil coating
}

\begin{abstract}
Blackberry is a fruit that has high nutritional value, a factor that has expanded its consumption worldwide. However, due to the fragility of the fruits and the high incidence of postharvest diseases, the fruits have a short shelf life. Thus, the objective of this study was to evaluate whether the application of coatings based on micro fibrillated cellulose (NC) and lemongrass essential oil (EO) nanoparticles can prolong the shelf life of blackberry fruits after harvest. EO-coated blackberry fruits at nanocellulose concentrations were analyzed as follows: $0 ; 0.2 ; 0.4 ; 0.6$ and $0.8 \%$, in addition to the control treatment of which neither essential oil nor nanocellulose was used, for each treatment five repetitions were used. The fruits were analyzed soon after the application of the cover and at three and six days after storage. Fruit quality was assessed by soluble solids (SS), titratable acidity (TA), $\mathrm{pH}$, fresh weight (FW) and colorimetric parameters such as luminosity, hue angle and fruit peel chroma. Coating on EO (1000 ppm) blackberries combined with $\mathrm{NC}$ at concentrations of $0.2,0.4$ and $0.6 \%$ is promising in preserving blackberry fruits and reducing the process color reversal, up to six days of storage. The $0.4 \% \mathrm{NC}+1000 \mathrm{ppm}$ EO conjugated coating showed no SS changes in blackberry fruits during the six days of storage.
\end{abstract}

Keywords: Morus sp, cellulose, Cymbopogon citratus, post-harvest quality
Volume 4 Issue 2 - 2020

\author{
Evaldo Leandro Potma da Silva,' Tereza \\ Cristina de Carvalho, ${ }^{2}$ Ricardo Antonio \\ Ayub, ${ }^{3}$ Mariana Celano Menezes de Almeida' \\ 'Agronomist, Laboratory of Biotechnology Applied to Fruit, \\ Ponta Grossa State University, Brazil \\ ${ }^{2}$ Agronomist, teacher of agronomy, Post doctoral student, Ponta \\ Grossa State University, Brazil \\ ${ }^{3}$ Agr Eng, Full Professor Biotechnology Lab, Applied to \\ Fruitculture, Ponta Grossa State University, Brazil
}

\begin{abstract}
Correspondence: Ricardo Antonio Ayub Department of Crop Science, Ponta Grossa State University, Uvaranas Campus, General Carlos Cavalcanti Avenue, 4748 - 84030-900, Ponta
\end{abstract} Grossa, Paraná, Brazil, Tel 55-42-32203088,Email rayub@uepg.br

Received: April 06, 2020 | Published: April 27, 2020

\section{Introduction}

Blackberry is part of the small fruits group, known for the high amount of antioxidants substances on its composition. It is very explored for the nutraceutical industry for protecting human body cells of the harms caused by free radicals, which are responsible for chronic diseases. ${ }^{1-4}$

Although blackberry has bioactives that directly attracts the consumer, the fruit has a fragile structure, which reduces its consumption in natura. ${ }^{5}$ Its lifespan is relatively short after harvesting, because of the high content of water, its metabolism and the occurrence of diseases demanding care with storage. ${ }^{6,7}$

The use of edible coating is one of the effective technological alternatives in extending the lifespan of fruits and vegetables. This is justified, because the material layer acts with excellent property as an artificial barrier, maintaining its postharvest quality, reducing production costs. ${ }^{8,9}$ According to Veerachandra\& Yen-Com,,${ }^{10}$ the use of coatings in food acts in the cross microbial reduction. This fact contributes to the maintenance of the viability of fruits that have a shorter postharvest life, such as blackberry.

Between the new perspectives of the use of coatings, cellulose can be highlighted. It is a natural polymer that, when reduced to nanocellulose, presents a crystalline structure with wide industrial applications. ${ }^{11}$ Its nanoscale dimension and its capacity of forming a strong nanoporous tangled network, encourage the emergence of new high value applications for the food industry. ${ }^{12}$

This particle has been widely studied as a component of materials, including food packaging. ${ }^{13}$ A benefit of the $\mathrm{NC}$ is its good water retention capacity, a feature that can be explored when applying coatings on fruits that have a high transpiratory rate. ${ }^{14}$ Water retention thus contributes to the durability of ready-to-eat foods ${ }^{15}$ especially due to the properties of the nano fibrillated cellulose, which has high strength and rigidity, low weight and biodegradability. The efficiency of this coat in the conservation of papaya fruits was verified by Trigo et al. ${ }^{16}$

At the same time, natural products extracted from medicinal plants are been studied as an alternative for the control of diseases and/ or reduction of degrading processes in fruits, mainly in postharvest conditions. ${ }^{17}$ Between these products, the OE shows themselves as a promising option. ${ }^{18}$

In this context, food industry is developing new packaging systems by incorporating EO or its main compounds into films. ${ }^{19}$ This could give them antimicrobial or antioxidant properties, improving shelf life of perishable food products. ${ }^{20}$

Lemongrass EO is an efficient and sustainable option in postharvest treatment, as it interrupts the development of microorganisms. ${ }^{21,22}$ Associated with other edible coatings, it is explored on guava postharvest. $^{23}$

Considering the blackberry short postharvest life and the importance this culture represents for the market, the objective of this work was to evaluate if the application of the coatings based on nanoparticles of nano fibrillated cellulose (NC) and lemon grass essential oil (EO) is able of extend the shelf life of blackberry fruits after harvest

\section{Material and methods}

Blackberry fruits of the cultivar Brazos were obtained from a commercial orchard in Ponta Grossa city, Paraná. The harvest was done during the morning and the fruits were immediately conduced to the laboratory, where they were washed in running water, dried with the aid of paper towels and divided into 90 (eighteen) portions of 40 grams (which corresponds to approximately 25 fruits), that were used to compose the treatments, as described in Table 1. At harvest, the selected fruits had the same maturation stage, aiming at uniformity of the experiment. 
Table I Description of the treatments used in the research

\begin{tabular}{|c|c|c|}
\hline \multicolumn{2}{|l|}{ Evaluation times } & $\begin{array}{l}\text { Nanocellulose (NC) and essential oil (EO) combinations } \\
\text { Control (without NC and EO) }\end{array}$ \\
\hline - After coating ( 0 days)- $3 r d$ days- $6 r d$ days $*$ & 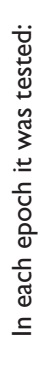 & $\begin{array}{l}0 \%(\mathrm{NC})+1000 \mathrm{ppm}(\mathrm{EO}) \\
0.2 \%(\mathrm{NC})+1000 \mathrm{ppm}(\mathrm{EO}) \\
0.4 \%(\mathrm{NC})+1000 \mathrm{ppm}(\mathrm{EO}) \\
0.6 \%(\mathrm{NC})+1000 \mathrm{ppm}(\mathrm{EO}) \\
0.8 \%(\mathrm{NC})+1000 \mathrm{ppm}(\mathrm{EO})\end{array}$ \\
\hline
\end{tabular}

*Note On the sixth day, no evaluation of fruits belonging to the control treatment was performed, as they deteriorated

To obtain the NC, pinewood residues submitted to acid hydrolysis with sulfuric acid in a cold-water bath to remove lignin were used. Passing through a filtration process, and, finally, dissolving in water to obtain the biofilm according to the methodology described by Ditzelet al. ${ }^{15}$

In order to obtain nanocellulose concentrations, the standard solution was diluted with $2 \%$ concentration in water to obtain the experimental solutions, obtaining $0.2 \%, 0.4 \%, 0.6 \%$ and $0.8 \%$. After preparing the $\mathrm{NC}$ solutions, lemon grass EO was added on each solution, at $1000 \mathrm{ppm}$ concentration, for all the treatments with $\mathrm{NC}$, as the methodology of et al. (2008).

The biofilm application was done by dipping the fruits in the solution with a waiting time of one minute and subsequent drying for complete adhesion to the fruit; the procedure being conducted at laboratoryat $25^{\circ} \mathrm{C}$ and $77 \%$ RH.Afterwards, the fruits were packed on closed plastic boxes, which allowed ventilation. The set was kept over a bench, in the laboratory, without sunlight exposition. After the fruit coating, the analyses were repeated after a storage period of three and six days.

On this way, a total of three evaluation periods were established, to know: right after harvest ( 0 days), at three and six days after fruit coverage. FoRozwalkar each evaluation periods, six $\mathrm{NC}+\mathrm{EO}$ combinations were analyzed: control (without $\mathrm{NC}$ and $\mathrm{EO}$ ), $0 \%$ $(\mathrm{NC})+1000 \mathrm{ppm}$ (EO), $0.2 \%(\mathrm{NC})+1000 \mathrm{ppm}(\mathrm{EO}), 0.4 \%(\mathrm{NC})+1000$ ppm (EO), $0.6 \%(\mathrm{NC})+1000 \mathrm{ppm}(\mathrm{EO})$ and $0.8 \%(\mathrm{NC})+1000 \mathrm{ppm}$ (EO). Still related to the treatments, on the sixth evaluation day for the treatment control, the fruits were discarded, because they were deteriorated and without possibility of been evaluated. The description of the treatments detailed is in Table 1.

Each treatment consisted of five 40 gram repetitions (approximately 25 blackberry fruits), each repetition being separately packaged in a previously identified plastic bag.

\section{The fruits were analyzed for the FW, colorimetry, SS,} AT and $\mathrm{pH}$

To obtain the FW (g), an analytical bench scale of the Shimadzu brand, model ATX224 was used, where the fruit was identified since the first day and was weighted every three days to evaluate the fresh weight loss. The final values were expressed in grams.

To the quality analysis, $\mathrm{SS}\left({ }^{\circ} \mathrm{Brix}\right), \mathrm{AT}(\%$ malic acid) and $\mathrm{pH}$ were evaluated. The SS were quantified using a Biosystems LTDA bench refractometer (model 103). The AT was quantified by titration with 0,1
$\mathrm{N} \mathrm{NaOH}$ and further calculated by the formula $[\mathrm{ATT}=(\mathrm{n} . \mathrm{N} . \mathrm{Eq}) / \mathrm{V}]$, where $\mathrm{n}$ is the volume of sodium hydroxide solution spent on titration in $\mathrm{mL}, \mathrm{N}$ is the normality of the sodium hydroxide solution, $\mathrm{V}$ is the sample volume in $\mathrm{mL}$ and $\mathrm{Eq}$ is the equivalent gram of malic acid.

The $\mathrm{pH}$ values were estimated with a tec 5 model TECNAL bench pHgameter.

To the fruit coloration, a Konica Minolta bench colorimeter was used. The L (lightening) parameters reading, $a^{*}$ and $b^{*}$ allowed to calculate the Hue angle and the Chroma or color saturation. The Hue angle is equivalent to the [tangent $\left.\operatorname{arc}\left(\mathrm{b}^{*} / \mathrm{a}^{*}\right)\right]$ and Chroma to $\left[\left(\mathrm{a}^{* 2}+\right.\right.$ $\left.\left.\mathrm{b}^{* 2}\right)^{1 / 2}\right]$ according to Minolta. ${ }^{24}$

\section{Statistical analysis}

The data were analyzed using a completely randomized design (CRD). In the statistical procedure, the subdivided plots were adopted, with $(3 \times 6)$ scheme, being the first factor evaluation days (immediately after harvest, at three and six days of storage) and the second, fruit coating $(0,0.2,0.4,0.6$ and $0.8 \% \mathrm{NC}+\mathrm{OE}$, and the absolute control without $\mathrm{NC}$ and $\mathrm{OE}$ ), with five repetitions. The averages were compared by the Student Newman Keulstest at $\mathrm{p} \leq 0.05$. When there was an interaction of the $\mathrm{NC} \mathrm{OE}$ concentrations in each evaluation period, the regression analysis was performed. All the data were computed and entered in Excel, looking for generate the tables and graphics. The statistical analysis was done using the program RStudio. $^{25}$

\section{Results and discussion}

The $\mathrm{pH}, \mathrm{AT}$, SS and FW results for blackberry fruits and the comparison of the results obtained between the different evaluation periods, right after coating application, at three and six days of storage are show inTable 2.

It is observed that $\mathrm{pH}$ values in blackberry fruits varies according to the used coating (Table 2). To the treatments with $\mathrm{OE}$ and $\mathrm{NC}$ at $0.2 \%$ and $0.8 \%$ concentrations at three and six days after storage, the highest $\mathrm{pH}$ values occurred. Already at six days of evaluation, coating with $\mathrm{EO}$ and $\mathrm{NC}$ at $0,0.4$ and $0.6 \%$ at the sixth day, had the higher $\mathrm{pH}$ values (Table 2). High $\mathrm{pH}$ values are indicatives of fruit deterioration. ${ }^{6}$ In this sense, lower $\mathrm{pH}$ values indicate fruits that are in less deterioration process. Thus, the best values were found for $\mathrm{OE}+\mathrm{NC}$ coating at the following values: $0.2 \%$ (immediately after coating application), $0.4 \%$ at three days of coating and 0.6 and $0.8 \%$ $\mathrm{NC}$ right after coating. 
Table 2 Average $\mathrm{pH}$ data, titratable acidity (TA), soluble solids (SS) and fresh weight (FW) of blackberry cv. Brazos treated with micro fibrillated nanocellulose coating associated with lemongrass essential oil, in function of the evaluation period.Where: (NC) nanocellulose and (EO) essential oil

\begin{tabular}{|c|c|c|c|c|c|c|}
\hline \multirow{2}{*}{ Evaluation after storage (days) } & \multicolumn{6}{|c|}{ Fruit treatment at postharvest } \\
\hline & Control & EO+NC $0 \%$ & EO+NC $0.2 \%$ & EO+NC $0.4 \%$ & EO+NC $0.6 \%$ & EO+NC $0.8 \%$ \\
\hline & $\mathrm{pH}$ & & & & & \\
\hline 0 & $3.05 \mathrm{~b}$ & $3.02 \mathrm{c}$ & $2.97 \mathrm{~b}$ & $3.06 \mathrm{c}$ & $3.08 \mathrm{c}$ & $2.95 \mathrm{~b}$ \\
\hline 3 & 3.37 a & $3.22 \mathrm{~b}$ & $3.38 \mathrm{a}$ & $3.52 \mathrm{~b}$ & $3.36 \mathrm{~b}$ & $3.45 \mathrm{a}$ \\
\hline 6 & - & $3.52 \mathrm{a}$ & $3.37 \mathrm{a}$ & $3.66 \mathrm{a}$ & $3.56 \mathrm{a}$ & $3.47 \mathrm{a}$ \\
\hline \multirow[t]{2}{*}{ CV (\%) } & 2.05 & & & & & \\
\hline & \multicolumn{6}{|c|}{ Titratable acidity (\% malic acid) } \\
\hline 0 & $3.07 \mathrm{a}$ & $1.54 \mathrm{a}$ & $2.18 \mathrm{a}$ & $2.30 \mathrm{a}$ & $2.05 \mathrm{a}$ & $1.80 \mathrm{a}$ \\
\hline 3 & $1.18 \mathrm{~b}$ & $\mathrm{I} .28 \mathrm{~b}$ & $1.28 \mathrm{~b}$ & $\mathrm{I} .28 \mathrm{~b}$ & $1.28 \mathrm{~b}$ & $1.28 \mathrm{a}$ \\
\hline 6 & - & $1.28 \mathrm{~b}$ & $1.28 \mathrm{~b}$ & $1.28 \mathrm{~b}$ & $1.28 \mathrm{~b}$ & $1.28 \mathrm{a}$ \\
\hline \multirow[t]{2}{*}{ CV (\%) } & 24.62 & & & & & \\
\hline & \multicolumn{6}{|c|}{ Soluble solids ( ${ }^{\circ}$ Brix) } \\
\hline 0 & $7.3 \mathrm{a}$ & $6.4 \mathrm{~b}$ & $6.5 \mathrm{ab}$ & $6.2 \mathrm{a}$ & $7.0 \mathrm{~b}$ & $5.9 \mathrm{~b}$ \\
\hline 3 & $7.2 \mathrm{a}$ & $8.2 \mathrm{a}$ & $5.9 \mathrm{~b}$ & $7.5 \mathrm{a}$ & $8.8 \mathrm{a}$ & $8.2 \mathrm{a}$ \\
\hline 6 & - & $6.0 \mathrm{~b}$ & $7.8 \mathrm{a}$ & $7.4 \mathrm{a}$ & $6.8 \mathrm{~b}$ & $6.0 \mathrm{~b}$ \\
\hline \multirow[t]{2}{*}{ CV (\%) } & 14.47 & & & & & \\
\hline & \multicolumn{6}{|c|}{ Fresh weight (g) } \\
\hline 0 & $5.15 \mathrm{a}$ & $5.27 \mathrm{a}$ & $5.27 \mathrm{a}$ & $5.50 \mathrm{a}$ & $4.97 \mathrm{a}$ & $5.76 \mathrm{a}$ \\
\hline 3 & $4.63 \mathrm{a}$ & $4.73 \mathrm{~b}$ & $4.85 \mathrm{~b}$ & $4.91 \mathrm{~b}$ & $4.50 \mathrm{~b}$ & $5.24 \mathrm{~b}$ \\
\hline 6 & - & $4.10 \mathrm{c}$ & $4.16 \mathrm{c}$ & $4.27 c$ & $3.94 \mathrm{c}$ & $4.50 \mathrm{c}$ \\
\hline CV (\%) & 5.68 & & & & & \\
\hline
\end{tabular}

Averages followed by the same lowercase letter in the column do not differ from each other by the Student Newman Keuls at p $\leq 0.05$. The treatments with "-" means that the evaluations were not performed because of the complete deterioration of the fruit

The process of fruit deterioration occurs due to the greater respiratory activity of the fruit. As cells breathe intensely, there is a higher consumption of sugars and organic acids contained in it. ${ }^{26}$ This fact reduces the fruit life span. The fruit coating with biofilms can limit the oxygen diffusion, reducing the respiratory rate and, consequently, the deterioration.

The TA of blackberry fruits (Table 2) coated with $\mathrm{NC}$ and lemongrass $\mathrm{EO}$ at $0.2,0.2$ and $0.6 \%$ concentrations presented the greatest acidity values, been this result obtained right after the coating of the fruits. It is worth noting that high values of titratable acidity are indicatives of the presence of organic acids, which confer flavor to the fruit. According to Hirsch et al. ${ }^{3}$ acidity is one of the important parameters used in classification of pulps for juice production. The $\mathrm{pH}$ and TA values coincide with those found by Turmanidze et al. ${ }^{27}$ where the application of edible coatings did not show significant changes during the fruit storage period.The average valued of TA coincide with the ones found by Curiet al. ${ }^{2}$ to the cultivar Brazos, these values are within what is accepted for the fruit's commercialization.

To the SS of blackberry fruits (Table 2), the highest ${ }^{\circ}$ Brix values were found to the $\mathrm{EO}+\mathrm{NC}$ coatings at concentrations of: $0.2 \%$ at the sixth day of evaluation, $0.6 \%$ and $0.8 \%$ at the third day of evaluation. The ${ }^{\circ}$ Brix is an indicative of the quantity of sugars in the fruits. The values obtained here (Table 2), ranged from 5.9 to $8.8^{\circ}$ Brix and some of these agree with Curi et al. ${ }^{2}$ who obtained $7.4{ }^{\circ}$ Brix for fruits of Brazos cultivar. However, these values can also be influenced by the management and climatic conditions of the plants in the field. According to Kafkas et $a .^{4}$ the accumulation of reducing sugars (glucose and fructose) is very important to the blackberry postharvest physiology, been responsible for the fruits sweet flavor.

With the progress of storage (Table 2), it is observed that the loss of fresh fruits decreases, especially when using the coating of blackberry fruits with nanocellulose and lemon grass essential oil. The smaller fresh fruit loss can be related to the low respiratory rate, because as the fruit tissues cells breathe, there is a sugar consumption contained on it. ${ }^{26}$ Other factors that interfere in the fresh weight loss reduction is the transpiration process, at storage temperature reduction. ${ }^{28}$

The use of fruit films alters the gas exchange between the vegetable and the external environment, through a lower respiratory quotient. ${ }^{29}$ This factor explains the variation in fresh mass loss obtained among coated fruits. ${ }^{30}$

According to Yamamoto et al. ${ }^{31}$ calcium chloride, which may be present in the chemical composition of some biofilms, when associated with the pectin present in the cell wall of the cells lining the fruit, forms covalent bonds rising calcium pectate, component responsible for the external fruit layer rigidity. ${ }^{32}$ This component acts reducing the transpirations and, consequently, the fresh weight loss of the fruit. 
The Figure 1 shows the blackberry behavior as different concentrations of $\mathrm{NC}$ were applied. It is worth noting that the periods of evaluation tendency lines ( 0,3 and 6 days) that showed significant differences are represented in isolation.

The AT (Figure 1B) and SS (Figure 1C), of blackberry fruits evaluated at six days after storage, presented values reduction tendency as there was an increase in NC concentration. High titratable acidity concentrations may indicate better fruit quality, because it confers flavor to the fruits.

The FW(Figure 1D) of blackberry fruits becomes higher as the NC concentration increased to $0.8 \%$. However, it is noteworthy that when

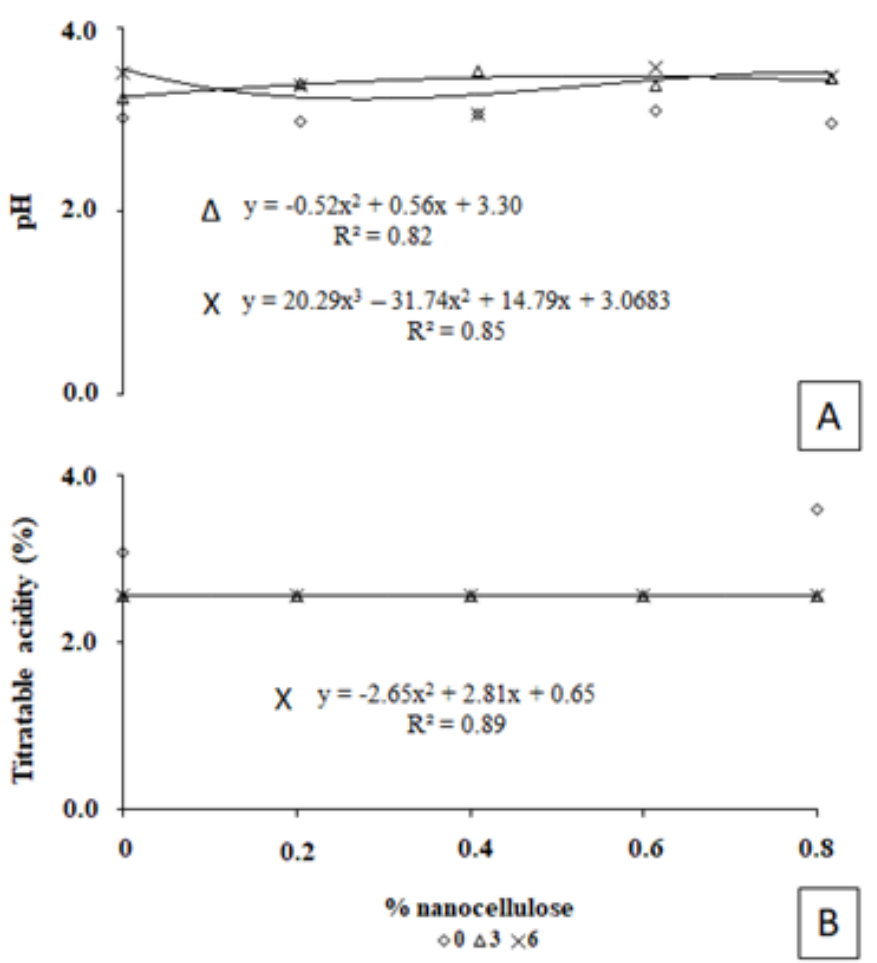

evaluating the individual effect of each NC concentration (Table 2), FW tends to reduce until the sixth day of storage.

To the blackberry fruits $\mathrm{pH}$ (Figure 1A), it was observed that the evaluation performed at three days after storage presented a $\mathrm{pH}$ reduction tendency as there were a $\mathrm{NC}$ concentration increase. Already to the fruits evaluated at six days, there is a $\mathrm{pH}$ stability with the NC concentrations increase (Figure 1A). The $\mathrm{pH}$ stability over the storage days and the SS increase do not coincide with the results found by Trigoet al ${ }^{16}$ where $\mathrm{pH}$ increases decreased SS concentration in papaya fruits tested and consequently there was a reduction of the color attributes such as Chroma.
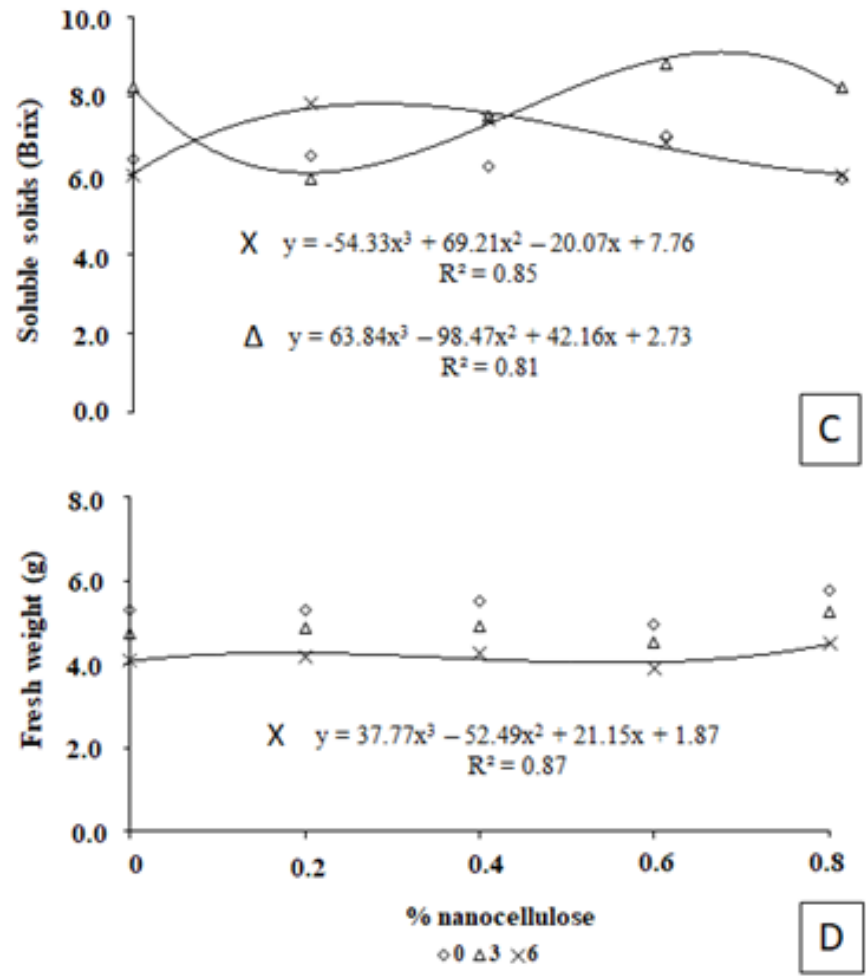

Figure I pH (A): $\mathrm{pH}$, titratable acidity (B), soluble solids (C) and fresh weight (D) of blackberry cv. Brazos, in function of the different nanocellulose associated with lemongrass essential oil concentrations.

The results of luminosity, Hue angle and Chroma for blackberry fruits are presented in Table 2. The comparison of the obtained results between the different evaluation periods, right after coating

application, at three and six days of storage (Table 3), records an oscillation of values between the analyzed treatments.

Table 3 Average luminosity data (*L), Hue angle (hue) and chroma (Chroma) of blackberries cv. Brazos treated with microfibrillated nanocellulose coating associated with lemongrass essential oil, in function of the evaluation period. Where: (NC) nanocellulose and (EO) essential oil

\begin{tabular}{|c|c|c|c|c|c|c|}
\hline \multirow{2}{*}{ Evaluation after storage (days) } & \multicolumn{6}{|c|}{ Fruit treatment at postharvest } \\
\hline & Controle & EO+NC $0 \%$ & EO+NC $0.2 \%$ & EO+NC $0.4 \%$ & EO+NC $0.6 \%$ & $\mathrm{EO}+\mathrm{NC} \mathbf{0 . 8 \%}$ \\
\hline & \multicolumn{6}{|c|}{ Luminosity $(* \mathrm{~L})$} \\
\hline 0 & $15.38 \mathrm{a}$ & $19.14 \mathrm{a}$ & $18.58 \mathrm{ab}$ & 18.11 a & $16.94 \mathrm{~b}$ & $16.68 \mathrm{a}$ \\
\hline 3 & $14.75 \mathrm{a}$ & $19.55 \mathrm{a}$ & $17.20 \mathrm{~b}$ & $15.62 \mathrm{~b}$ & $17.66 \mathrm{ab}$ & $16.10 \mathrm{a}$ \\
\hline 6 & - & $18.26 \mathrm{a}$ & $20.32 \mathrm{a}$ & $19.82 \mathrm{a}$ & $19.69 \mathrm{a}$ & I5.85 a \\
\hline
\end{tabular}


Table Continued...

\begin{tabular}{|c|c|c|c|c|c|c|}
\hline \multirow{2}{*}{ Evaluation after storage (days) } & \multicolumn{6}{|c|}{ Fruit treatment at postharvest } \\
\hline & Controle & EO+NC 0\% & EO+NC $0.2 \%$ & EO+NC $0.4 \%$ & EO+NC $0.6 \%$ & EO+NC $0.8 \%$ \\
\hline \multirow[t]{2}{*}{ CV (\%) } & 9.60 & & & & & \\
\hline & Hue Angle & & & & & \\
\hline 0 & $26.80 \mathrm{a}$ & $17.86 \mathrm{a}$ & $17.74 \mathrm{a}$ & $17.98 \mathrm{~b}$ & $20.52 \mathrm{a}$ & $18.98 \mathrm{a}$ \\
\hline 3 & $29.86 \mathrm{a}$ & $16.83 \mathrm{a}$ & $15.95 \mathrm{a}$ & $29.00 \mathrm{a}$ & $14.11 \mathrm{a}$ & $22.04 \mathrm{a}$ \\
\hline 6 & - & 17.07 a & $15.96 \mathrm{a}$ & $16.43 \mathrm{~b}$ & $22.21 \mathrm{a}$ & $29.30 \mathrm{a}$ \\
\hline \multirow[t]{2}{*}{ CV (\%) } & 35.04 & & & & & \\
\hline & Chroma & & & & & \\
\hline 0 & $1.10 \mathrm{a}$ & $9.12 \mathrm{a}$ & $10.20 \mathrm{~b}$ & 18.11 a & 16.94 b & $16.68 \mathrm{a}$ \\
\hline 3 & $1.78 \mathrm{a}$ & $10.52 \mathrm{a}$ & $9.67 \mathrm{~b}$ & $15.62 \mathrm{~b}$ & $17.66 \mathrm{ab}$ & $16.10 \mathrm{a}$ \\
\hline 6 & - & $8.15 \mathrm{a}$ & $13.73 \mathrm{a}$ & $19.82 \mathrm{a}$ & $19.69 \mathrm{a}$ & $15.84 \mathrm{a}$ \\
\hline CV (\%) & 25.29 & & & & & \\
\hline
\end{tabular}

Averages followed by the same lowercase letter in the column do not differ from each other by the Student Newman Keulsat $\mathrm{p} \leq$ 0.05 . The treatments with "-" means that the evaluations were not performed because of the complete deterioration of the fruit.

The Hue angle (Table 3) showed no significative differences for $\mathrm{EO}+\mathrm{NC}$ concentrations at $0,0.2,0.6$ and $0.8 \%$ regardless of the evaluation period. For the control treatments and $\mathrm{OE}+\mathrm{NC}$ at $0.4 \%$ concentration, on the third day of evaluation the fruits already had the highest Hue angle values (Table 3).

When analyzing the average values of Chroma (Table 3), it is observed that the blackberry fruits coating with $\mathrm{OE}+\mathrm{NC}$ at concentrations of $0.2,0.4$ and $0.6 \%$, determined at six days of storage presented the highest values (Table 3 ). These results are indicative of better fruit quality $(\mathrm{OE}+\mathrm{NC} 0.2,0.4$ and $0.6 \%)$, as it is an indicative of the fruit color intensity, that is, higher values indicate more intense samples which pleases consumers. ${ }^{3}$

Observing the fruit luminosity results (Table 3), the application of EO+NC coating at $0.2,0.4$ and $0.6 \%$ presented high luminosity values at six days of storage. These results are indicative of better fruits quality, because the higher is the luminosity, the better is the visual quality of the blackberry fruits, as it keeps a shine that pleases the final consumer. ${ }^{28}$

Maintaining the postharvest life and quality of blackberries is a challenge for growers and packers due to several postharvest problems, including fresh weight loss and color reversal. ${ }^{24,33}$ Looking for reducing these losses, the use of techniques as cooling and the use of packaging became viable alternatives. ${ }^{6}$ According to Bischoff et al. (2013), blackberry hue decreases during the storage days due to the fruit water content reduction. It is observed by the luminosity results (Table 3 ) that even at six days of storage, the blackberry coating with $\mathrm{EO}+\mathrm{NC}$ at $0.2,0.4$ and $0.6 \%$ concentrations are promising in maintaining their quality.
According to Hirsch et al..$^{3}$ the hue angle is a variable that is between $0^{\circ}$ and $90^{\circ}$, and the smaller the angle value, the redder the fruit. Such fact is not desirable for blackberry fruits, whose desirable color in the market is purple. Lower Hue values suggest that the fruits began to appear reddish over the days. This reddish appearance of the fruits pericarp (exocarp) is known as the blackberry color reversal process. The color reversal process is undesirable for producers as it impairs the fruits appearance and, consequently, reduces the value of the final product to consumers. ${ }^{34}$

Chroma values may be associated with the influence of the coating film color, which has a whitish coloration and are also linked to the increase of the fruit's SS over the storage days due to the starch retrogradation into smaller sugar molecules. ${ }^{16}$

Figure 2 shows the behavior of blackberry fruits as different concentrations of $\mathrm{NC}$ are used, as for luminosity (A), Hue angle (B) and Chroma (C). It is noteworthy that the tendency lines of the evaluation periods $(0,3$ and 6 days) that presented significative differences are been displayed in isolation.

It is observed that the blackberry fruits luminosity (Figure 2A), for fruits evaluated at six days after storage, the peak value was $0.4 \%$ $\mathrm{EO}+\mathrm{NC}$. The fruit color changes its luminosity and is an important parameter for producers and consumers as it indicates if the fruit has or not ideal conditions for its commercialization and consumption, ${ }^{3}$ as preferably strong and bright color.

The average Hue angle data (Figure 2B) for blackberry fruits evaluated at six days of storage show an increasing value trend as the concentration of $\mathrm{NC}$ increased. Thus, at six days of storage, the increase in the $\mathrm{NC}+\mathrm{EO}$ concentrations used for coverage keeps the blackberry fruits in their original coloration, not allowing the fruits to change their coloration to a reddish skin coloration.

As for the average values of Chroma, there is a tendency of value reduction, as the NC concentrations increase, both for fruits evaluated 
right after harvest and for those evaluated at six days after storage (Figure 2C). However, it is noteworthy that the individual evaluation of each $\mathrm{NC}$ concentration (Table 3), especially for the $\mathrm{EO}+\mathrm{NC}$ coatings at concentrations $0.2,0.4$ and $0.6 \%$, gave at six days of evaluation, the highest Chroma values.

The lower luminosity values (Figure 2A), were found in the control treatments, $0 \% \mathrm{NC}=\mathrm{EO}$, and with the highest concentrations of $\mathrm{NC}+\mathrm{EO}(0.6$ and $0.8 \%)$ and may result from alteration of some molecular structure of starch, which is responsible for increasing the fruit opacity. The brightness decreases with the ripening of blackberry fruits, indicating that the color becomes more intense or darker. The appearance of the purple color may be related to the appearance of phenolic compounds..$^{34,35}$
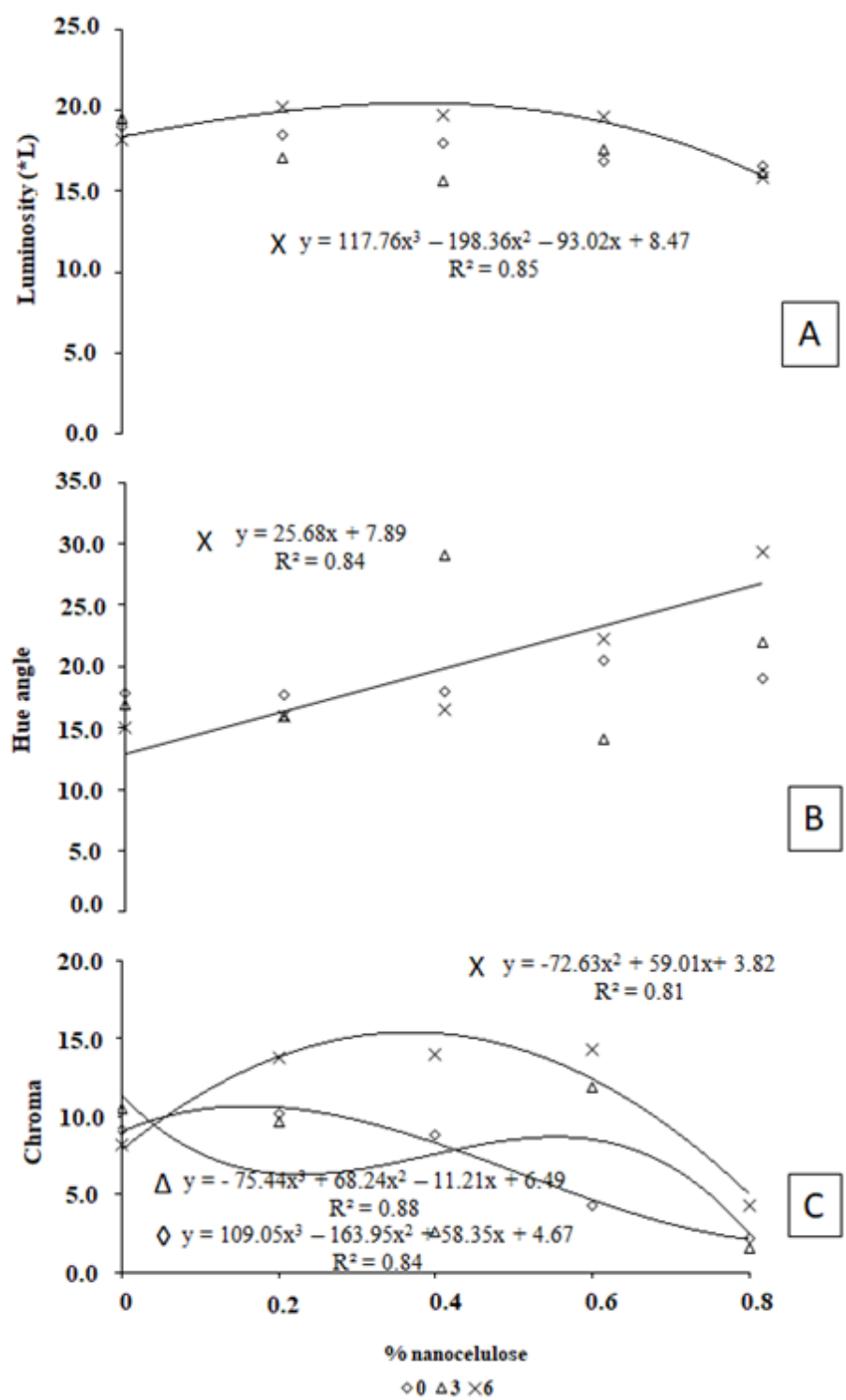

Figure 2 Luminosity $\left({ }^{*} \mathrm{~L}\right)(\mathrm{A})$, Hue angle (B) and Chroma (C) of blackberry cv. Brazos, in function of different nanocellulose associated with lemongrass essential oil concentrations.

\section{Conclusion}

The application of coating associating lemongrass EO (1000ppm) and $\mathrm{NC}$ at $0.2,0.4$ and $0.6 \%$ concentrations are promising in blackberry fruits conservation until six days of postharvest.The blackberry fruit coating with $0.4 \% \mathrm{NC}+1000 \mathrm{ppm}$ of EO did not present SS changes during the six days of storage.

The visual appearance of the blackberry fruits, postharvest coated with $1000 \mathrm{ppm}$ of lemongrass EO associated with $0.2,0.4$ or $0.6 \%$ of $\mathrm{NC}$, maintains characteristics that retard the fruits color reversal process, up to six storage days.
New nanocellulose and EO combinations should be tested to extend potential use of berry biofilms.

\section{Conflicts of interest}

The authors declare have no conflict of interest about the publication of this paper.

\section{References}

1. Barbieri RL, Vizzotto M. Pequenas frutas ou frutas vermelhas. Informe Agropecuário, Belo Horizonte. 2012;33(268):7-10. 
2. Curi PN. et al. Production of blackberry and redberry in Lavras - MG, Brazil. Ciência Rural. 2014;45(8):1368-1374.

3. Hirsch, G.E. et al. Physical-chemical characterization of blackberry varieties from southern Brazil. Ciência Rural. 2012;42(5):942-947.

4. Kafkas, E. et al. Analysis of sugars, organic acids and vitamin c contends of blackberry genotypes from Turkey. Food Chemistry. 2006;97(4):732736.

5. Oliveira DM. et al. Biodegradable coatings on the postharvest of blackberry stored under refrigeration. Ciência Agronômica. 2013; 44(2):302-309.

6. Bischoff TZ, Pintro CT, Paloschi CL, et al. Post-harvest conservation of refrigerated blackberry with biofilm and plastic packaging. Revista Energia Na Agricultura. 2103;28(2):109-114.

7. Palharini, MCA, Fischer IV, Vegian MRC, et al. Effect of storage temperature on post-harvest conservation of blackberry. Pesquisa Agropecuária Tropical. 2015;45(4):413-419.

8. Sena, E.O.A. et al. Use of edible biofilm in post-harvest conservation of green peppers (Capsicum Annuum L.). Scientia Plena. 2016;12(8):1-9.

9. Gol NB, Vyas PB, Rao TVR. Evaluation of polysaccharide-based edible coatings for their ability to preserve the postharvest quality of indian blackberry (Syzygium Cumini L.). International Journal Of Fruit Science. 2015;15(2):198-222.

10. Veerachandra KY, Yen-Com H. Photocatalytic Tio2 coating of plastic cutting board to prevent microbial cross-contamination. Food Control. 2017;77:88-95.

11. Kim JH, Shim BS, Kim HS, et al. Review of nanocellulose for sustainable future materials. International Journal of Precision Engineering And Manufacturing-Green Technology. 2015;2(2):197-213.

12. Lavoine N, et al. Microfibrillated celulose - its barrier properties and applications in cellulosic materials: a review. Carbohydrate Polymers. 2012;90(2):735-764.

13. Nsor-Antidana J. Functionality and nutricional aspects of microcrystalline cellulose in food. Carbohydrate Polymers. 2017;172:159-174.

14. Ditzel FI. Nanocrystalline cellulose extracted from pine wood and corncob. Carbohydrate Polymers. 2017;157:1577-1587.

15. Cazón P, Velazquez G, Ramírez JA, et al. Polysaccharide-based films and coatings for food packaging: a review. Food Hydrocolloids. 2017;68:136148.

16. Trigo JM. Efeito de revestimentos comestíveis na conservação de mamões minimamente processados. Brazilian Journal of Food Technology. 2012;15(2):125-133.

17. Carnelossi PR. Essential oils in the post-harvest control of colletotrichum gloeosporioides in papaya. Revista Brasileira de Plantas Medicinais. 2009;11(4):399-406.

18. Lorenzetti ER, Monteiro FP, Souza PE, et al. Bioactivity of essential oils in the control of botrytis cinerea isolated from strawberry. Revista Brasileira De Plantas Medicinais. 2011;13:619-627.

19. Balooch $\mathrm{M}$, et al. Intercalation technique can turn pomegranate industrial waste into a valuable by-product. Lwt-Food Science And Technology. 2018;98:99-105
20. Dhital R. Efficacy of limonene nano coatings on post-harvest shelf life of strawberries. Lwt-Food Science and Technology. 2018;97:124-134.

21. Santos Neto J, Estrada KRFS, Sena JOA, et al. Quality of tomato fruits grown in organic production system and treated with lemon grass byproduct. Revista Ciência Agronômica. 2016;47(4):633-642.

22. Bermudez-Vasquez MJ, Granados-Chinchila F, Molina A. Chemical composition and antimicrobial activity of the essential oil of psidium guajava and cymbopogon citratus. Agronomia Mesoamericana. 2019;30(1):147-163.

23. Rozwalka LC. Extracts, decoctions and essential oils of medicinal and aromatic plants in the inhibition of colleototrichum gloeosporioides and glomerella cingulate isolates from guava fruits. Ciência Rural. 2008;38(2):301-307.

24. Minolta. Precise color communication: color control from feeling to instrumentation. Osaka: Minolta Co. Ltda. 1994.

25. Rstudio. Undelete and data recovery software. Software livre de ambiente de desenvolvimento integrado para r para análises estatísticas. 2018.

26. Taiz L, Zeiger E. Fisiologia Vegetal. 5th edn, Porto Alegre: Artmed Editora, 2013:918.

27. Turmanidze, TV. Effect of calcium chloride treatments on quality characteristics of blackberry fruit during storage. International Journal of Food And Allied Sciences. 2016:2(2):36-41.

28. Soethe C, Steffens CA, Amarante CVT, et al. Qualidade, compostos fenólicos e atividade antioxidante de amoraspretas 'tupy' e 'guarani' armazenadas a diferentes temperaturas. Pesquisa Agropecuária Brasileira. 2016;51(8):950-957.

29. Luvielmo MM, Lamas SV. Revestimentos comestíveis em frutas. Estudos Tecnológicos Em Engenharia. 2012;8(1):8-15.

30. Menezes KRP. Influência dos revestimentos comestíveis na preservação da qualidade pós colheita de tomate de mesa. Colloquium Agrariae. 2017;13(3):14-28.

31. Yamamoto, E.L.M. et al. Função do cálcio na degradação da parede celular vegetal. Revista verde de agroecologia e desenvolvimento sustentável. 2011;6:49-55.

32. Deng Y, Wu Y, Li Y. Changes in firmness, cell wall composition and cell wall hydrolases of grapes stored in high oxygen atmospheres. Food Researech International.2005;38:769-776.

33. Lawrence B, Melgar JC, Harvest, handling, and storage recommendations for improving postharvest quality of blackberry cultivars. Horttechnology. 2018;28(5):578-583.

34. Tosun I, NS, Tekguler B. Physical and chemical changes during ripening of blackberry fruits. Scientia Agricola. 2008;65(1):87-90.

35. Sethu KMP, Prabha TN, Tharanathan RN. Post-harvest bicochemical changes associated with the softening phenomenon in capsicum annuum fruits. Phytochemistry. 1996;42:961-966. 